Portland State University

PDXScholar

7-12-1974

\title{
Infection of smallmouth bass and goldfish by two species of Saprolegnia
}

Cheryl A. McGinley

Portland State University

Follow this and additional works at: https://pdxscholar.library.pdx.edu/open_access_etds

Part of the Biology Commons, and the Marine Biology Commons Let us know how access to this document benefits you.

\section{Recommended Citation}

McGinley, Cheryl A., "Infection of smallmouth bass and goldfish by two species of Saprolegnia" (1974). Dissertations and Theses. Paper 2166.

https://doi.org/10.15760/etd.2163

This Thesis is brought to you for free and open access. It has been accepted for inclusion in Dissertations and Theses by an authorized administrator of PDXScholar. Please contact us if we can make this document more accessible: pdxscholar@pdx.edu. 
AN ABSTRACT OF THE THESIS OF Cheryl A. McGinley for the Master of Science in Biology presented July 12, 1974.

Title: Infection of Smallmouth Bass and Goldfish by Two Species of Saprolegnia.

APPROVED BY MEMBERS OF THE THESIS COMMITTEE:

Byron E. Lippert, Chairman

Thelma N. Fisher

Richard R. Petersen

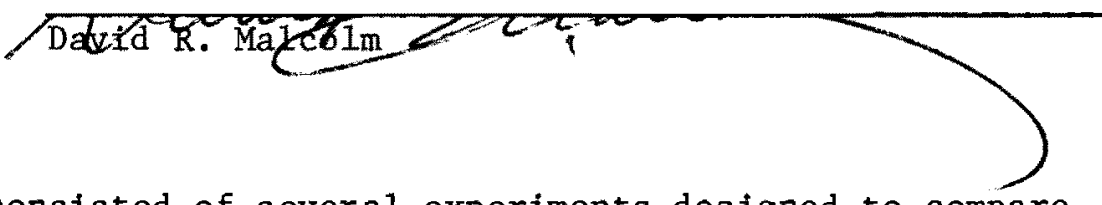

This study consisted of several experiments designed to compare the ability of two species of fungi, Saprolegnia ferax and $\underline{s}$. parasitica, to grow on two species of $\mathrm{fish}$, smallmouth bass (Micropterus dolomieui) and goldfish (Carassius auratus), and to determine the criteria necessary for the development of these infections.

The results indicate that water in the fish tanks must be slightly acid (pH 6), warm $\left(22^{\circ} \mathrm{C}\right)$, nonmoving, and that the fish must be wounded 
in order for fungal infection to occur. Cool water $\left(18^{\circ} \mathrm{C}\right)$ and moving water, caused by aeration and filtration, are detrimental to fungal colony formation so that no infection occurs.

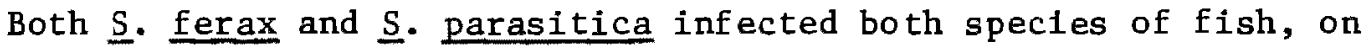
an average of three days after innoculation. The $\underline{S}$. ferax infected a higher percentage of both fishes than did the $\underline{s}$. parasitica. The difference in susceptibllity of the two fish species to the fungi was negligible. 


\title{
INFECTION OF SMALLMOUTH BASS AND GOLDFISH \\ BY TWO SPECIES OF SAPROLEGNIA
}

$$
\text { by }
$$

CHERYL A. MCGINLEY
A thesis submitted in partial fulfillment of the requirements for the degree of

\author{
MASTER OF SCIENCE \\ in \\ BIOLOGY
}

\author{
Portland State University \\ 1974
}


TO THE OFFICE OF GRADUATE STUDIES AND RESEARCH:

The members of the Committee approve the thesis of Chery1 A. McGinley presented July 12, 1974.

Byron E. Lippert, Chairman

Thelma N. Fisher

Richard R. Petersen

1

Tatid R. Malcoln?

APPROVED :

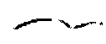

$\bar{E} \operatorname{ar} 1$ Fishier, Jr., Head, Department of Biology

David T. Clark, Dean of Graduate Studies and Research 


\section{ACKNOWLEDGMENTS}

The writer would like to express her appreclation to Dr. B.E. Lippert for his advice and assistance in this study, for checking over the manuscript, and espectally for his patience and sense of humor this last year. Appreclation is also extended to the Oregon State Game Commission for donating the bass used in the experimentation. 
TABLE OF CONTENTS

PAGE

ACKNOWLEDGMENTS . . . . . . . . . . . . . . . . 1 . 1 . .

LIST OF TABLES . . . . . . . . . . . . . . . . . . . . . . v v

LIST OF FIGURES . . . . . . . . . . . . . . . . . . vi v vi

INTRODUCTION . . . . . . . . . . . . . . . . . 1

Description of the Problem .............. 5

MATERIALS AND METHODS ..................... . . . 7

RESULTS . . . . . . . . . . . . . . . . 9 9

DISCUSSION . . . . . . . . . . . . . . . . . . 16

Suggestions for Further Research . . . . . . . . . 20

SUMMARY . . . . . . . . . . . . . . . . . . . 21

CONCLUSIONS . . . . . . . . . . . . . . . . . . . 22

LITERATURE CITED . . . . . . . . . . . . . . . . . 23 


\section{LIST OF TABLES}

TABLE

PAGE

I Tanks Filtered and Aerated, Temperature $18^{\circ} \mathrm{C} . . . . .10$

II Tanks Aerated, Not Filtered, Temperature $18^{\circ} \mathrm{C}$. . . . . 11

III Tanks Not Filtered, Not Aerated, Temperature $18^{\circ} \mathrm{C}$. . . 12

IV Tanks Not Filtered, Not Aerated, Temperature $22^{\circ} \mathrm{C}$. . . 13 


\section{LIST OF FIGURES}

1 S. ferax oogonium .................. 2

2 S. parasitica oogontum . . . . . . . . . . . . . 2

3 S. ferax zoosporangium ................ 3

4 S. parasitica zoosporangium .............. 3

5 Life cycle of Saprolegnia . . . . . . . . . . . 4

6 Smallmouth bass, showlng fungal growth . . . . . . . 14

7 Goldfish, showing fungal growth . . . . . . . . . 14 


\section{INTRODUCTION}

Members of the Saprolegniaceae, a family of water fungi, are observed to grow on various fresh water fish under natural and controlled conditions. Many of these water molds commonly found on fish and fish eggs, in fresh water lakes and streams, belong to the genus Saprolegnia. Thís genus occurs naturally in fresh water, and is reported world wide. It is characterized by a branched, coenocytic, white mycelium, macroscopically visible which grows upon pieces of organic matter. Microscopically it features zoosporangia which are typically long, clavate, thickened at the distal end, and terminally located on the hyphae (Alexopoulos, 1962). In this study two species of this genus, $\underline{S}$. ferax and $\underline{S}$. parasitica, are compared as to their abilities to establish growth on smallmouth bass and goldfish.

The two species of Saprolegnia are distinguished by morphological characteristics of the sex organs, and asexual zoosporangia. $\underline{\text { S. ferax }}$ has prominent pits in the oogonial walls (Figure 1), whereas $\underline{\text { s. para- }}$ sitica has smooth unpitted oogonial walls (Figure 2) (Wolf, 1944). The zoosporangia of $\underline{S}$. Eerax are typically of unequal diameter throughout, tapering toward the ends (Figure 3); the zoosporangia of $\underline{\text { S. parasitica }}$ tend to be long cylindrical, and bent (Figure 4) (Wolf, 1944).

Three stages in the life cycle of Saprolegnia are capable of initiating growth on organic matter: the encysted secondary zoospores, and oospores, both of which germinate and grow hyphae, and the rhizoidal hyphae of a growing colony (Figure 5). 


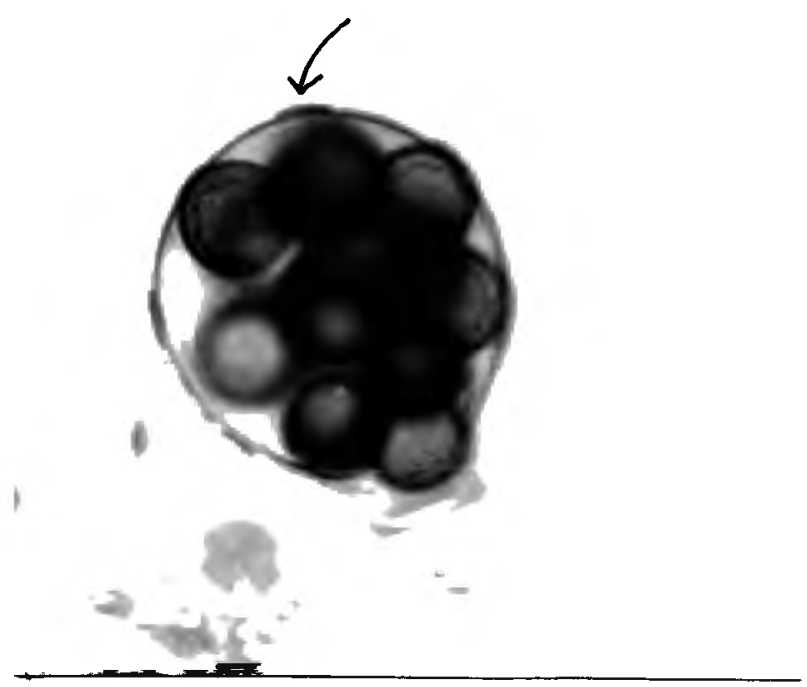

Figure 1. S. ferax oogonium. 500X. Pits visible on outside wall, eggs visible within.

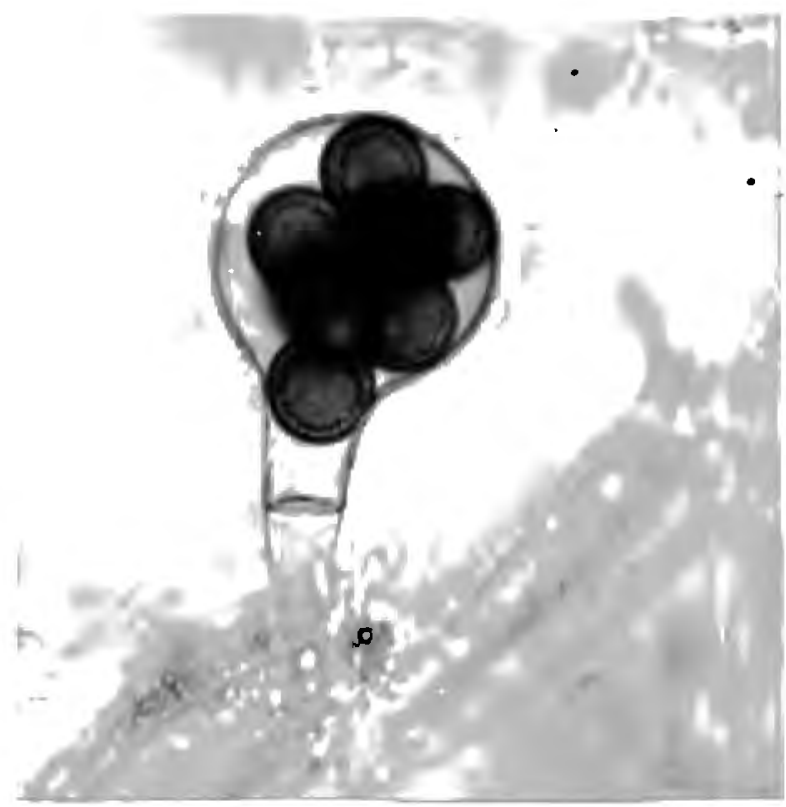

Figure 2. S. parasitica oogonium. 500x. Nonpitted wa11, eggs visible within. 


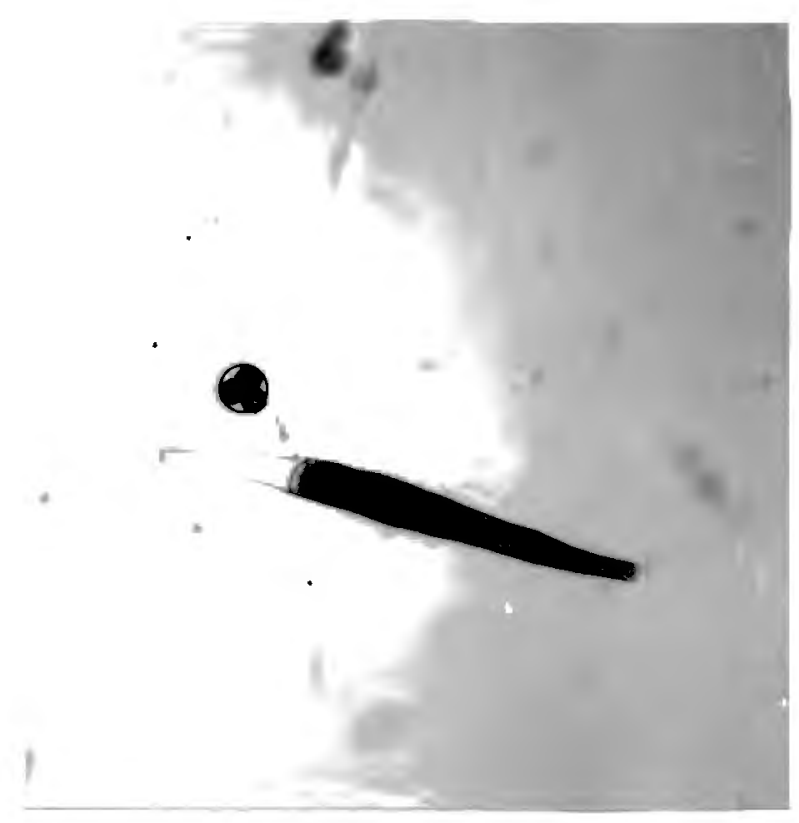

Figure 3. S. ferax zoosporangium. 125x. Structure typically tapers toward end.

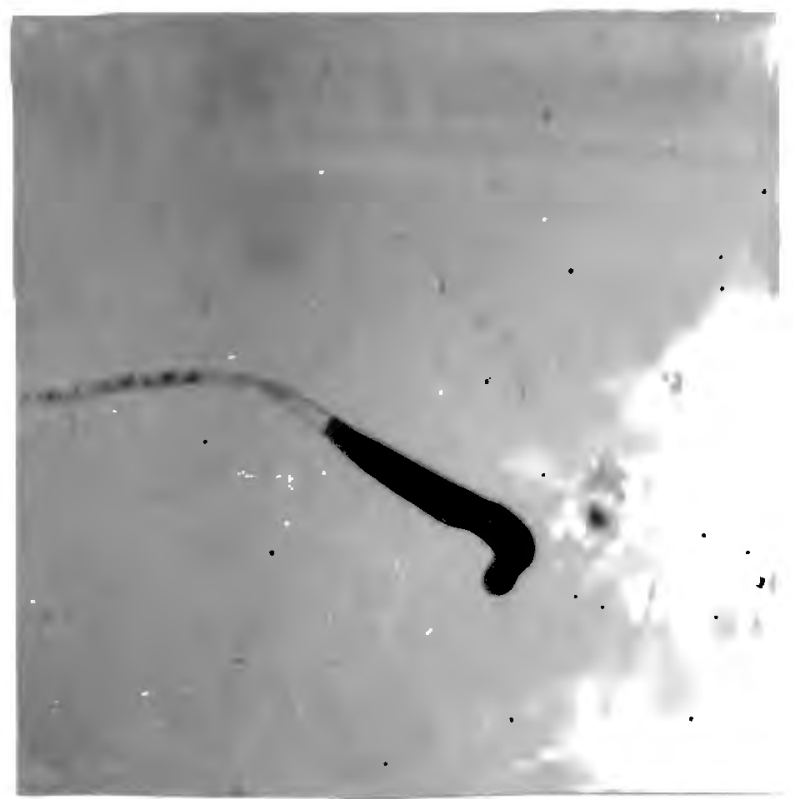

Figure 4. S. parasitica zoosporangium. 125X. Structure commonly bent. 

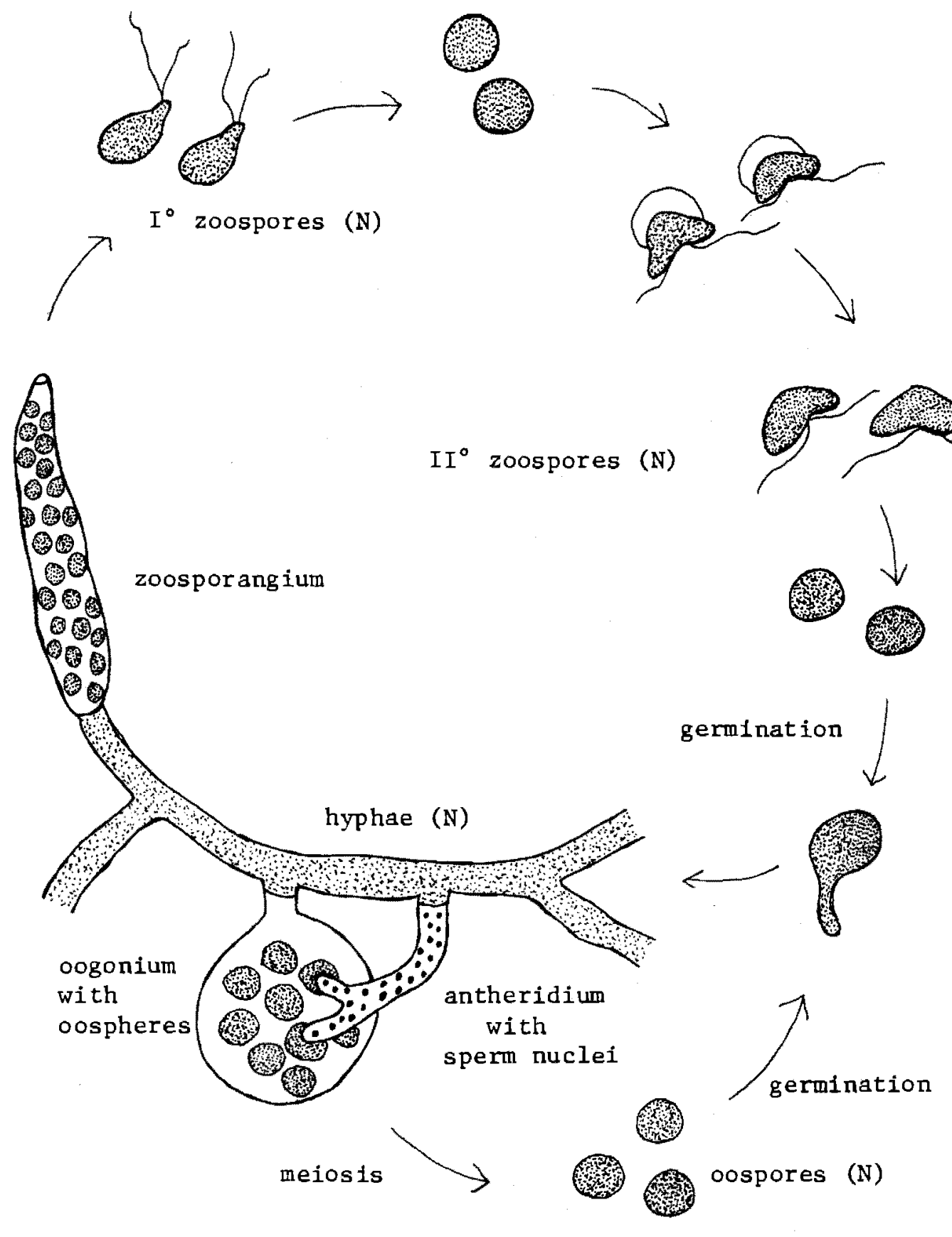

Figure 5. Life cycle of Saprolegnia 
Kanouse (1932) has demonstrated that the two fungal species differ both physiologically and morphologically, thus possibly indicating variability in infectivity. Both species of fungi have been identified as being capable of externally parasitizing some fresh water fish in nature such as trout, salmon, carp, shad, roach, dace, perch, catfish, bream, eels, pike, black bass, and others (Tiffney, 1939a; Tiffney, 1939b; Scott and O'Bier, 1962); the above fungi are capable also of infecting under laboratory conditions (Kanouse, 1932; Tiffney, 1939a; Vishniac and Nigrelli, 1957; Scott, 1964).

Juvenile common goldfish (Carassius auratus), and smallmouth bass (Micropterus dolomieui) were selected as the test species of fish to be innoculated with fungi. Both fish belong to the class of bony fishes, Pisces. Goldfish are members of the carp-minnow family (Cyprinidae), whereas smallmouth bass belong to the sunfish family (Centrarchidae). Both fish live in relatively warm waters $\left(15-24^{\circ} \mathrm{C}\right)$, and are propagated in outdoor pools; bass are raised for sport fisheries, while goldfish are propagated for commercial purposes. Neither laboratory nor natural infections of these species of Saprolegnia are reported in the literature for smallmouth bass; natural and laboratory induced infections are known to occur in goldfish by an unknown species of

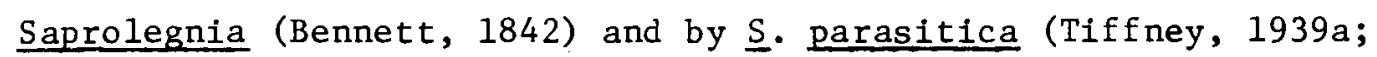
Martin, 1968).

\section{Description of the Problem}

Experiments were performed to compare the ability of two species

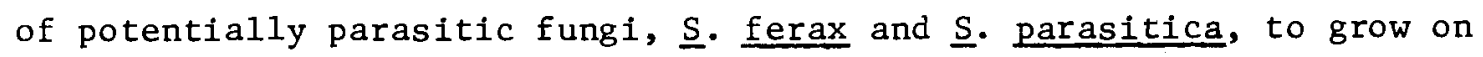
two species of warm water fish, $\underline{M}$. dolomieui and $\underline{C}$. auratus, and to 
determine the criteria necessary for the development of these

infections. Modifications in $\mathrm{pH}$, temperature, and water movement, in conjunction with wounding and nonwounding of $\mathrm{fish}$, are reported in an attempt to establish fungal growth. The time between innoculation and appearance of fungal hyphae on fish is also recorded. 
MATERIALS AND METHODS

Pure cultures of $\underline{S}$. ferax and $\underline{S}$. parasitica were obtained from the American Type Culture Collection. Stock cultures were maintained on sterilized hemp seeds (Cannabis sativa) in flasks and petri dishes containing sterilized distilled water at $23^{\circ} \mathrm{C}$ (Kanouse, 1932; Dick, 1965).

Smallmouth bass (‥ dolomieui) were obtained from rearing ponds of the Oregon State Game Commission at St. Paul, Oregon. These animals were juvenile fish about one year old, measuring from three to three and one half inches in length. Sexually the fish were indistinguishable, since sexual maturity does not occur until about the fourth year (Lagler, 1956). Goldfish (‥ auratus) were purchased from a commercial outlet in Portland. Like the bass, these were juvenile fish also, about four to five months old, which measured between one and two inches. Both species of fish were kept in large wooden tanks which were filtered, kept at $18^{\circ} \mathrm{C}$, and maintained at a pH of approximately 6.5. Goldfish were fed trout feed, while the bass were fed live tubifex worms. Under testing conditions, a total of twelve randomly selected fish of one species were placed in two four gallon glass tanks filled with water from stock tanks. Three of the fish in each tank were wounded by making a longitudinal cut along the right hand side of the dorsal fin, approximately one centimeter long, with a sterilized razor blade. Cuts were made through scales and dermal layers into the dorsal muscle, but not deeply enough to incapacitate the fish. This procedure was a modi- 
fied version of that used by Tiffney (1939a) and Vishniac and Nigrelli (1957) .

Ten to fourteen day old fungal cultures, exhibiting good zoospore production, were used to innoculate the tanks of fish. Two large mycelial mats of each species, approximately three and one half inches in diameter, were added directly to the tanks along with some growth media. Every three days a few sterilized hemp seeds cut in half were added to the tanks to encourage fungal growth.

Tank conditions were progressively altered in an attempt to promote visible growth on the fish. Tanks previously aerated and filtered were left unaerated and unfiltered; $\mathrm{pH}$ was allowed to change and eventually stabilize between 6 and 6.5 . The maintenance temperature of $18^{\circ} \mathrm{C}$ known to be ideal for fish propagation (Lagler, 1956) was gradually raised to $22^{\circ} \mathrm{C}$. The latter conditions provided a temperature much more favorable for fungal metabolic processes (Saksena and Bhargava, 1941), but less favorable for growth of fish.

Individual trials were run for no more than seven days, since previous work had recorded infections occurring in shorter intervals (Scott and O'Bier, 1962; Scott, 1964). Time between innoculation and visible growth on the fish was recorded in all cases. The appearance of the macroscopic growth on the fish was the criterion used to measure for parasitism. Filaments of the fungi were removed from infected fish and cultured on hemp seeds in order to verify that the fungus was the innoculum species. 


\section{RESULTS}

As long as test tanks were either aerated and/or filtered neither species of fish, whether wounded or not, became infected with either S. ferax or $\underline{S}$. parasitica (Tables I and II). Water movement, even though moderate, proved to be detrimental to the fungal colonies because their formation was disrupted. Fish were not parasitized by either fungus as long as the water temperature was kept at $18^{\circ} \mathrm{C}$, a preferred temperature for these fish (Tables I, II, and III).

Only under conditions involving a warmer temperature $\left(22^{\circ} \mathrm{C}\right)$ suitable for fungal growth, and where there was no water movement nor filtration would the fungi grow on any of the fish, and then only if the fish had been wounded (Table IV). Fung1 grew from wounded areas on the fish and spread along the dorsal fin (Figures 6 and 7). When fungal growth did develop it generally occurred about three days after test tanks had been innoculated with a given fungus. In each case fungal hyphae were removed from infected fish, recultured on hemp seeds, and identified as the innoculum species.

Tests indicated that $\underline{S}$. $\underline{\text { ferax }}$ was more consistent in infecting wounded fish than was $\underline{\mathrm{S}}$. parasitica. A total of $88 \%$ of the smallmouth bass and $94 \%$ of the goldfish were infected by $\underline{5}$. ferax, whereas S. parasitica grew on $68 \%$ of the bass and $78 \%$ of the goldfish. In calculating a chi square value (2.67), the differences between the two fungi were acceptable at the five percent level of significance. In comparing fungal infectivity of the two fish species it seemed that 
TABLE I*

TANKS FILTERED AND AERATED, TEMPERATURE $18^{\circ} \mathrm{C}$

S. $\underline{\text { ferax }}$

Infected Noninfected
S. parasitica

Infected Noninfected

Bass

Wounded

0

9

0

9

Nonwounded

0

9

0

9

\section{Goldfish}

Wounded

0

9

0

9

Nonwounded

0

9

0

9

* Total of 3 trials 


$$
\text { TABLE II }{ }^{*}
$$

TANKS AERATED, NOT FILTERED, TEMPERATURE $18^{\circ} \mathrm{C}$
S. $\underline{\text { ferax }}$
S. parasitica

Infected Noninfected

Infected Noninfected

\section{Bass}

Wounde

0

9

0

9

Nonwounded

0

9

0

9

\section{Goldfish}

\begin{tabular}{lllll} 
Wounded & 0 & 9 & 0 & 9 \\
Nonwounded & 0 & 9 & 0 & 9 \\
\hline & *Total of 3 trials
\end{tabular}


TABLE III ${ }^{*}$

TANKS NOT FILTERED, NOT AERATED, TEMPERATURE $18^{\circ} \mathrm{C}$

S. ferax

S. parasitica

Infected Noninfected

Infected Noninfected

Bass

Wounded

0

9

0

9

Nonwounded

0

9

0

9

Goldfish

\begin{tabular}{lllll} 
Wounded & 0 & 9 & 0 & 9 \\
Nonwounded & 0 & 9 & 0 & 9 \\
\hline & *Total of 3 trials
\end{tabular}


TABLE IV *

TANKS NOT FILTERED, NOT AERATED, TEMPERATURE $22^{\circ} \mathrm{C}$

S. ferax $\quad \underline{\text { S. parasitica }}$

Infected Noninfected Infected Noninfected

\section{Bass}

Wounded

16

2

12

6

Nonwounded

0

18

0

18

Goldfish

\begin{tabular}{lcccc} 
Wounded & 17 & 1 & 14 & 4 \\
Nonwounded & 0 & 18 & 0 & 18 \\
\hline & & $*_{\text {Total of }} 6$ trials
\end{tabular}




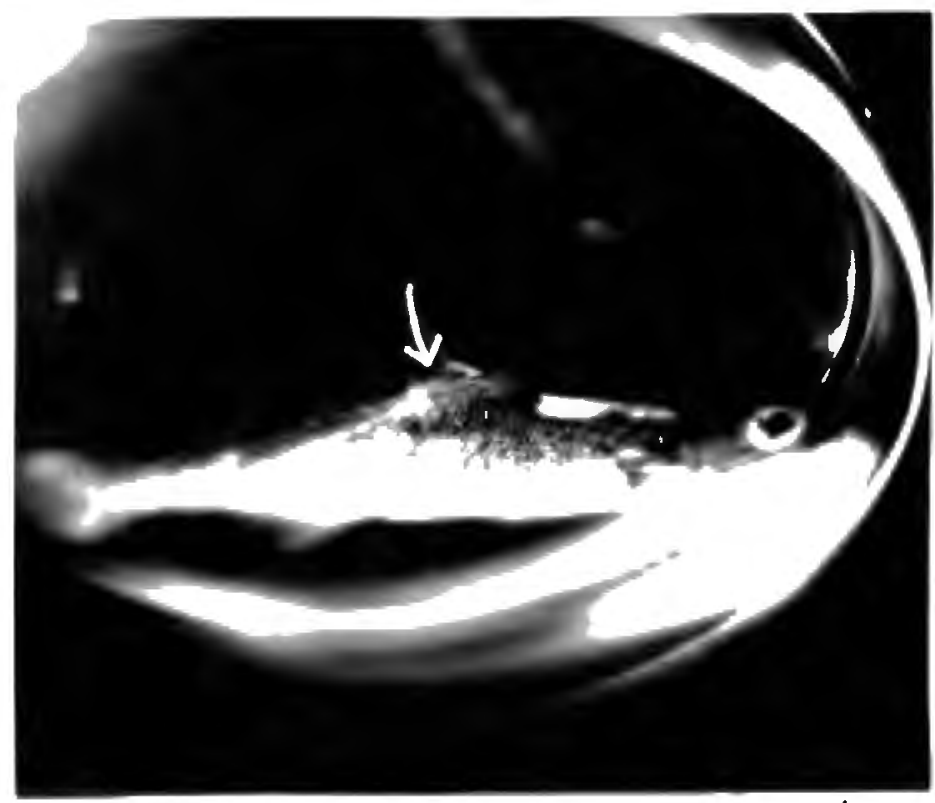

Figure 6. Smallmouth bass, showing fungal growth from wound alongside dorsal fin.

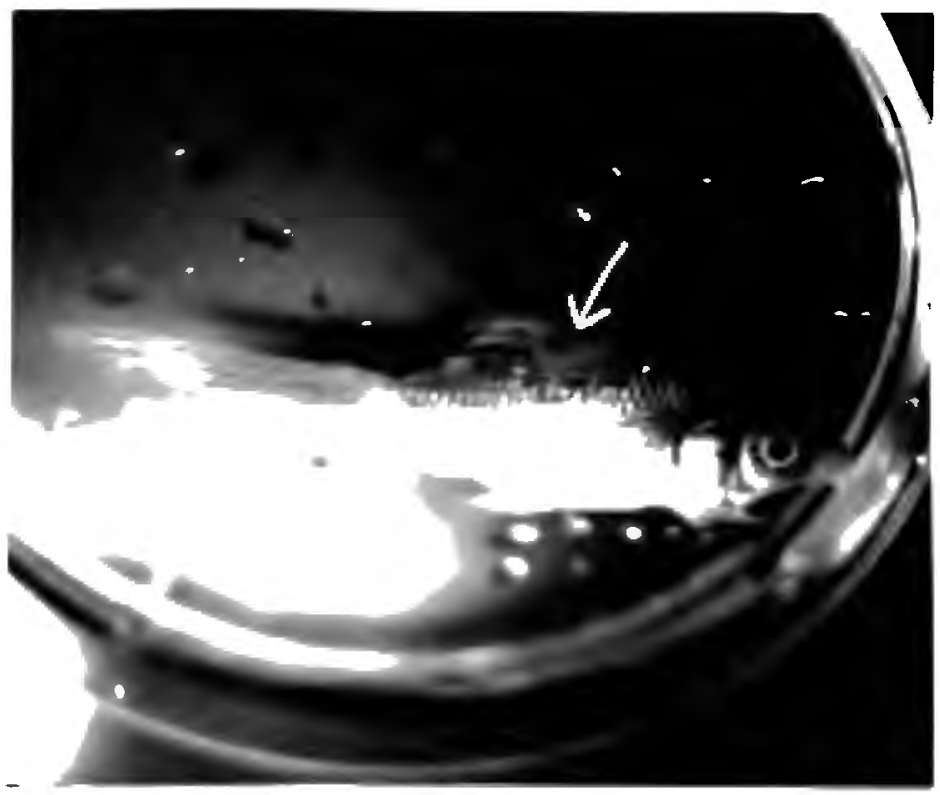

Figure 7. Goldfish, showing fungal growth from wound alongside dorsal fin. 
the differences between infected goldfish and bass were negligible. None of the trials resulted in infection of nonwounded living fish. However it was observed that in several instances where uninjured fish died of concussion the fungus engulfed thelr bodies within twentyfour hours. 
DISCUSSION

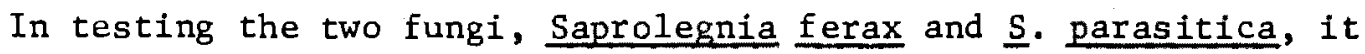
was found that they were capable of infecting goldfish and smallmouth bass if the water was slightly acid $\left(\mathrm{pH}^{6}\right)$, large colonies of fungus were present, there was no water movement, the temperature was at an optimum for fungal growth $\left(22^{\circ} \mathrm{C}\right)$, and the fish were wounded. Once this enviroment was established the two fungi were found to vary in their abilities to infect. $\underline{\text { S}}$ ferax was much more consistent in growing on

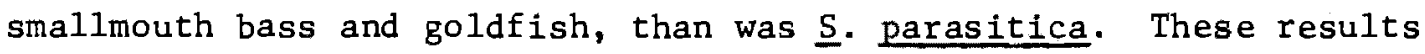
were not as dramatic as those of Vishniac and Nigrelli (1957) and Scott and O'Bier (1964) where they demonstrated that wounded platties (Xiphophorus maculatus) were attacked and killed by both $\underline{S}$. ferax and S. parasitica $100 \%$ of the time. This was a higher infectivity rate than that achieved in these experiments with goldfish and smallmouth bass. Whereas Vishniac and Nigrelli (1957) and Scott and O'Bier (1964) recorded $100 \%$ pathogenicity for wounded and nonwounded platties infected with both fungi, results reported in this thesis indicated that $\underline{\text { S. ferax }}$ infected $94 \%$ of the goldfish and $88 \%$ of the bass, while S. parastica infected $78 \%$ of the goldfish and $68 \%$ of the bass. Perhaps a lower infectivity rate was the result of using different test species of $\mathrm{fish}$, as well as due to differences in origin of $\mathrm{fungal}$ cultures. Divergence in qualities noted for the two spectes of fungi is probably correlated with their morphological and physiological dissimilarities as demonstrated by Kanouse (1932). Bhargava (1943) 
showed that enzyme activities varied between two other species of Saprolegnia, $\underline{S}$. delica and $\underline{S}$. monotca. Perhaps similar disparittes resulted with $\underline{S}$. ferax and $\underline{S}$. parasitica.

of the greatest significance are the results indfcating that only wounded fish are parasitized, and even then not $100 \%$ of the time. According to work done with platties by Scott and O'Bier (1964), these fungi are capable of infecting and killing both wounded and nonwounded fish within 24 hours. In this study an average of three days was required for growth to appear on wounded goldfish and smallmouth bass. Perhaps inconsistencies reported are because of species differences of fish and their susceptibilities to the fungi, as well as due to obvious size discrepancies of the three types of fish. Scott and O'Bier (1964), and Stuart and Fuller (1968) imply that these fungi act as primary invaders; my results suggest that fungi act as secondary invaders following initial damage caused by viruses, bacteria, parasttes, or wounding. Tiffany (1932a) and Vishniac and Nigrelli (1957) also believe that fungi act as secondary invaders, since their work indicates that open wounds on fish are required for fungal infection. In goldfish suffering from furunculosis, bacteria such as Aeromonas and Pseudomonas are the primary invaders of tissue; fungal growth is secondary (Mawdesley-Thomas, 1969). Likewise, in the Salmon disease, ulcerative dermal necrosis, fungal growth is secondary in ulcerated tissue - (Stevenson, 1970). It seems reasonable to assume that in nature these saprobic fungi are secondary invaders of lesions caused by wounding or microbial disease, and that the extensive amount of tissue damage reported in these diseases is due to proteolytic activity of accompany- 
ing bacteria.

Just as the two fungi showed a difference in infectivity, $\underline{\text { f }}$ ferax being more infectious, there was also a difference in the susceptibility of the two fish. Smallmouth bass were more resistant to infection by both species of the fungi, whereas goldfish were more often infected by fungi. Differences in susceptibilities, physiologies, and natural immunities of the fish could account for these results. It was demonstrated that Atlantic Salmon produced antibodies to Saprolegnia species (Hodkinson and Hunter, 1970), therefore it was reasonable to assume that goldfish and bass could do likewise.

Establishing the right conditions to promote infection in the fishes was the most difficult part of the experiment. The $\mathrm{pH}$ of the water was allowed to become slightly acid, due to waste product accumulation. Whiffen (1945) showed that species of Saprolegnia grew best under acid conditions ( $\mathrm{pH} 4-6)$, thus no attempt was made to alter the $\mathrm{pH}$ chemically, and the $\mathrm{pH}$ of the water was allowed to develop naturally as might occur in a quiet pool full of fish.

Results Indicated that water movement, whether by aeration or filtration was detrimental to fungal colony formation, in that it dispersed them. Aeration and filtration were used originally to simulate natural conditions of moderate water movement, removal of solid waste products, and to achieve turnover of water at the surface for oxygen exchange. It would seem reasonable to assume that under natural conditions where water movement was adequate, that fungal growth on fish would be detered because moving water would act as a cleansing mechanism. 
Temperature was the other major factor considered. At $18^{\circ} \mathrm{C}$, the temperature established to be optimum for growth and metabolism of both species of fish (Lagler, 1957; Innes, 1967), no infection occurred. Only at a higher temperature $\left(22^{\circ} \mathrm{C}\right)$ conducive for fungal replication (Saksena and Bhargava, 1940) did growth on any of the fish become evident. These results contradicted data reported from two investigations carried out with eels (Hoshina and Ookubo, 1956) and brown trout (Stuart and Fuller, 1968) where Saprolegnia growth on diseased fish became evident when water temperatures dropped below $18^{\circ} \mathrm{C}$. In these observations however, the fish were subjected to low temperatures which probably caused chilling in the fish and lowered their resistance, thereby making them susceptible to any invader.

Knowledge of the criteria necessary for infection of fish by these fungal species is important for establishing fish rearing techniques. Smallmouth bass are raised in Oregon and other states for sport fisheries; goldfish are propagated in Florida and Hong Kong for commercial purposes as aquaria fish and as food fish for other fish. Both of these species are reared by the pond farming technique (Lagler, 1957; Zah1, 1973); the probability of massive fungal infection exists if the fungus is growing on organic matter in quiet ponds which may be crowded with sick or wounded fish. Undoubtedly such cases only occur under conditions of neglect, but they are possible and point to the need for diligence and proper maintenance of rearing ponds in order to avoid such situations. In addition to monitoring the health of the fish, implementation of continually flowing water through ponds is suggested as a good preventive measure. 
Examination of the results of these experiments indicates that it is highly improbable that goldfish or smallmouth bass become parasitized by $\underline{\text { S}}$. $\underline{\text { ferax }}$ or $\underline{\text { S. }}$ parasitica under natural living conditions, whether in properly maintained aquaria or in the streams and lakes where smallmouth bass and some goldfish live. It is conceivable that old, sick and/or wounded fish become infected by fungi in nature, but that healthy fish are not susceptible on a large scale.

\section{Suggestions for Further Research}

In the types of studies reported, laboratory experimentation is limited and somewhat artificial. It is preferable to conduct similar studies using outdoor ponds, which simulate the natural environment and duplicate conditions as used presently for outdoor pond rearing practices. The effect of oxygen content, a full scale of varying temperatures, as well as $\mathrm{pH}$ changes should be tested with various $\mathrm{f}$ ish and fungi, before and after subjecting the fish to other microbial agents.

It is advisable also to use different strains of fungi obtained from various sources around the world, such as from natural waters, diseased fish, and laboratory maintained cultures. Quite possibly there are differences within the same species as concerns their abilities to infect the test fish. 
SUMMARY

This study consisted of several experiments designed to compare the ability of two species of fungi, Saprolegnia ferax and $\underline{S}$. parasitica, to grow on two species of fish, smallmouth bass (Micropterus dolomieu1) and goldfish (Carassius auratus), and to determine the criteria necessary for the development of these infections.

The results indicate that water in the fish tanks must be slightly acid $(\mathrm{pH} 6)$, warm $\left(22^{\circ} \mathrm{C}\right)$, nonmoving, and that the fish must be wounded in order for fungal infection to occur. Cool water $\left(18^{\circ} \mathrm{C}\right)$ and moving water, caused by aeration and filtration, are detrimental to fungal colony formation so that no infection occurs.

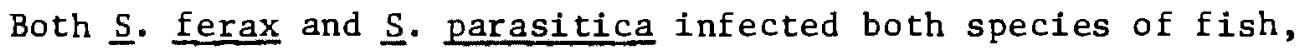
on an average of three days after innoculation. The $\underline{s}$. ferax infected a higher percentage of both fishes than did the $\underline{S}$. parasitica. The difference in susceptibility of the two fish species to the fungi was negligible. 


\section{CONCLUSIONS}

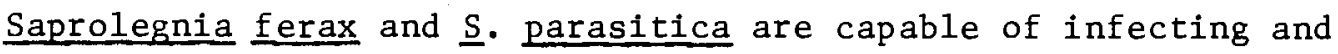
growing on both smallmouth bass (Micropterus dolomieui) and goldfish (Carassius auratus) under certain conditions. The conditions determined to be conducive to fungal infections involve a combination of factors; the water has to be warm $\left(22^{\circ} \mathrm{C}\right)$, the $\mathrm{pH}$ slightly acid (pH 6), the water has to be still, and the fish have to be wounded.

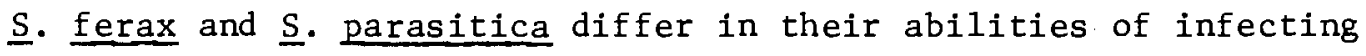
the two fish species. $\underline{S}$. ferax consistently infects a higher percentage

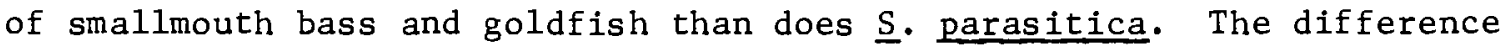
in susceptibility of the two fish species to the fungi was negligible. 


\section{LITERATURE CITED}

Alexopoulos, Constantine J. 1962. Introductory Mycology, John Wiley and Sons, New York, 138-149.

Bennet, J.H. 1842. "On the Parasitic Fungi Found Growing on Living Animals," Trans. Roy. Soc. Edinburgh, 15:18.

Bhargava, K.S. 1943. "Physiological Studies of Some Members of the Saprolegniaceae," J. Ind. Bot. Soc. 22(2/4):85-99.

Dick, M.W. 1965. "Maintenance of Stock Cultures of Saprolegniaceae," Mycologica, 57:828-830.

Hodkinson, Madeline and Alan Hunter. 1970. "Immune Response of U.D.N. Infected Salmon to Saprolegnia," J. Fish. Biol. 2:305-311.

Hoshina, T. and N. Ookubo. 1956. "On a Fungi Disease of Ee1," I. Univ. Tokyo Fisheries, 42:1-13.

Innes, William T. 1966. Exotic Aquarium Fishes, Metaframe Corp., Maywood, New Jersey.

Kanouse, Bessie B. 1932. "A Physiological and Morphological Study of Saprolegnia parasitica," Mycologica, 24(5):431-455.

Lagler, Karl F. 1956. Freshwater Fishery Biology, W.M.C. Brown Co., Dubuque, Iowa.

Martin, R.L. 1968. "Comparison of Effects of Concentrations of Malachite Green and Acriflavine on Fungi Associated with Diseased Fish," Prog. Fish Cu1t. 30(3):153-158.

Mawdesley-Thomas, L.E. 1969. "Furunculosis in Goldfish," J. Fish. Biol. 1:19-23.

Saksena, R.K. and K.S. Bhargava. 1941. "A Physiological Study of Saprolegnia delica Coker," Proc. Nat. Acad. Sci. Ind. 11:27-40.

Scott, William W. and Aaron H. O'Bier. 1962. "Aquatic Fungi Associated with Diseased Fish and Fish Eggs," Prog. Fish Cult. 24(1):3-15.

Scott, William W. 1964. "Fungi Associated with Fish Diseases," Develop. Indust. Microbiol. 5:109-123.

Stevenson, John P. 1970. "Scourge of the Salmon," New Scientist, $45: 353-354$. 
Stuart, Mary R, and Hubert T. Fuller, 1968. "Mycological Aspects of Diseased Salmon," Nature, 217:90-92.

Tiffney, Wesley N. 1939a. "The Host Range of Saprolegnia parasitica," Mycologica, 31(3):310-321.

Tiffney, Wesley N. 1939b. "The Identity of Certain Species of the Saprolegniaceae Parasitic to Fish," J. Elish. Mitch. Sci. Soc. $55(1): 134-151$.

Vishniac, Helen S. and R.F. Nigrelli. 1957. "The Ability of the Saprolegniaceae to Parasitize Platyfish," Zoologica, 42(4):131-135.

Whiffen, Alma J. 1945. "Nutritional Studies of Representatives of Five Genera in the Saprolegniaceae," J. Elish. Mitch. Sci. Soc. $61(1 / 2): 114-123$.

Wolf, Frederick T. 1944. The Aquatic Oomycetes of Wisconsin, University of Wisconsin Press, Madison, Wisconsin.

Zah1, Paul A. 1973: "Those Outlandish Goldfish," Nat. Geograph. $143(4): 514-533$. 